\title{
Pancreatic Enzymes Decreased
}

National Cancer Institute

\section{Source}

National Cancer Institute. Pancreatic Enzymes Decreased. NCI Thesaurus. Code C78520.

A laboratory test result which indicates decreased levels of pancreatic enzymes in a

biologic specimen. 